\title{
Molecular characterization of estuarine bacterial communities that use high- and low-molecular weight fractions of dissolved organic carbon
}

\author{
Joseph S. Covert, Mary Ann Moran* \\ Department of Marine Sciences, University of Georgia, Athens, Georgia 30602-3636, USA
}

\begin{abstract}
The composition of bacterial communities growing at the expense of high-molecular weight (HMW $;>1000 \mathrm{Da}$ ) and low-molecular weight (LMW; $<1000 \mathrm{Da}$ ) fractions of dissolved organic carbon from a southeastern US estuary was determined by sequencing and terminal restriction fragment length polymorphism (T-RFLP) analysis of 16S rRNA gene amplicons in 2 enrichment studies. 16S rDNA sequence analysis indicated that the bacterial communities growing on the LMW fraction were dominated by $\gamma$ - and $\varepsilon$-Proteobacteria related to Pseudomonas fluorescens and Arcobacter nitrofigilis (accounting for $90 \%$ of the clones) while the communities using the HMW fraction were dominated by $\alpha_{-}, \beta-$, and $\gamma$-Proteobacteria and Cytophaga-Flexibacter-Bacteroides related to Rhizobium-Agrobacterium, Janthinobacterium lividum, Pseudomonas fluorescens, Marinobacterium georgiense, Pseudoalteromonas, and Sphingobacterium comitans (accounting for $98 \%$ of the clones). Methylotrophic bacteria were present in the inoculum community but not found in either LMW or HMW enrichments. T-RFLP analysis of the enrichment communities showed measurable changes in community composition during the enrichment period, and companion respiration assays confirmed utilization of sufficient HMW and LMW carbon to support several bacterial generations. Although the composition of the estuarine inoculum used for the 2 enrichment studies (conducted in April 1997 and May 1999) was quite similar, the communities developing on the HMW and LMW fractions differed between experiments, potentially reflecting temporal variations in the chemical composition of the dissolved organic carbon.
\end{abstract}

KEY WORDS: Dissolved organic carbon (DOC) - Ultrafiltration · Terminal restriction fragment length polymorphism (T-RFLP) analysis · Bacterial community composition · 16S rDNA

\section{INTRODUCTION}

Dissolved organic carbon (DOC) predominates in many aspects of carbon cycling and trophodynamics in aquatic ecosystems. One technique with wide application for the study of DOC cycling is tangential flow ultrafiltration, which fractionates DOC based on differences in molecular weight by continual circulation of sample across ultrafilters. Tangential flow ultrafiltration has been successfully applied to DOC studies in both freshwater and marine ecosystems. These studies have shown that components of DOC can turn over at

*Corresponding author. E-mail: mmoran@arches.uga.edu distinctly different rates, and have led to the identification of DOC classes that are rapidly cycled by biological processes (Meyer et al. 1987, Amon \& Benner 1994, 1996).

The high molecular weight (HMW) fraction of DOC (defined here as DOC with a nominal molecular weight greater than $1000 \mathrm{Da}$ ) can contain large, labile polysaccharides which are rapidly taken up by bacteria, particularly in algal influenced systems, such as the open ocean (Amon \& Benner 1994, 1996). Yet HMW DOC can also contain refractory compounds which are not readily decomposed, such as humic substances in vascular plant-influenced systems (Meyer et al. 1987, Hopkinson et al. 1998). Likewise, the low 
molecular weight (LMW) components of DOC (DOC less than $1000 \mathrm{Da}$ ) can contain highly labile sugars and amino acids (Coffin 1989, Keil \& Kirchman 1991) as well as the refractory remains of larger biomolecules that have already been extensively processed microbially (Amon \& Benner 1996). In specific investigations of DOC turnover rates of molecular weight fractions, Ford \& Lock (1985) and Meyer et al. (1987) found the LMW fraction supported more bacterial growth in several river systems, while Amon \& Benner $(1994,1996)$ found the HMW fraction to be the most bioavailable in open ocean settings.

To this point, studies of DOC cycling in aquatic ecosystems have focused primarily on the rates at which bacteria utilize DOC, with little emphasis on the identity of the bacteria responsible for uptake. This 'microbial black box' approach has been dictated by the difficulties involved in culturing environmental bacteria, which prevent detailed study of the identity and capabilities of individual bacteria. Techniques borrowed from molecular biology, however, have revolutionized our understanding of bacteria in the environment by allowing identification of bacteria without requiring that they be brought into culture. These new techniques have allowed the characterization of bacteria involved in a variety of biogeochemical processes, from the cycling of organic sulfur in oceanic algal blooms (González et al. 2000) to the cycling of particulate organic matter in estuarine and coastal ecosystems (Crump et al. 1999) and are now being brought to bear on the turnover of specific DOC components (Cottrell \& Kirchman 2000a).

Our objective was to compare the composition of estuarine bacterial communities that utilize HMW and LMW fractions of DOC. We asked whether different molecular weight size classes of DOC, presumably with different chemical composition and cycling rates, support inherently different assemblages of bacteria. DOC from an estuary in the southeastern US was fractionated via ultrafiltration into HMW and LMW components, and used in bacterial enrichment studies as the sole source of carbon. Bacterial activity in the enrichments was quantified by measuring bacterial respiration rates, while bacterial community composition was determined by clone library and T-RFLP analysis of PCR-amplified 16S rRNA genes.

\section{MATERIALS AND METHODS}

Sample collection. Water samples were collected from the Satilla River, a blackwater river on the coastal plain of Georgia, USA, with average DOC concentrations of 10 to $30 \mathrm{mg} \mathrm{Cl}^{-1}$ (Moran et al. 1999). Water for DOC processing (40 to 80 l) was collected from the freshwater portion of the Satilla River, above the head of tide (Atkinson, GA) in April 1997 and May 1999. Water for the bacterial inoculum (20 1) was collected at the same time from the mouth of the estuary, in St. Andrews Sound (salinities of 30 and 32 psu in April 1997 and May 1999). All samples were collected in acid-washed Nalgene carboys that were rinsed with sample prior to collection.

Organic matter processing. Samples for DOC processing were sequentially filtered through $5 \mu \mathrm{m}$ (Osmonics, Inc., Minnetonka, MN), 1.0 and $0.2 \mu \mathrm{m}$ (Corning-Costar, Cambridge, MA) cartridge filters to remove particles and bacteria. To account for ionic strength changes occurring in the estuary and subsequent effects on DOC molecular weight distribution (Covert et al. unpubl.), the filter-sterilized Satilla River water was amended with a sea salts mixture to match the salinity of the site where the estuarine bacterial inoculum was collected. A commercial sea salts mixture (Sigma Inc., St. Louis, MO) was used for the salt amendment in the April 1997 sample, and a 5 component inorganic sea salts mixture (Ramette et al. 1977) in the May 1999 sample. Samples were then processed through an Amicon DC 10-L ultrafiltration unit (Millipore Corporation, Bedford, MA) containing two 1000 nominal molecular weight cut-off (MWCO) filters (S1Y10, Millipore Corp.). Prior to ultrafiltration, the membranes were washed with $0.2 \mathrm{~N} \mathrm{NaOH}$ and rinsed with copious volumes of Biograde purified water (Solution Consultants, Inc., Jasper, GA), and a small volume (4 l) of the saltamended sample was flushed through the system to precondition the membranes (Buesseler et al. 1996). The ultrafiltration separated the organic matter into HMW and LMW fractions. Finally, ultrafiltered concentrates were diafiltered with 20 to $40 \mathrm{l}$ of Biograde water to remove salts. All glassware was combusted or washed with $10 \% \mathrm{HCl}$ to avoid contamination.

Measurements of DOC concentration were made before and after the ultrafiltration process to determine carbon mass balance. DOC samples $(10 \mathrm{ml})$ were collected in combusted glass vials and stored at $4{ }^{\circ} \mathrm{C}$. Immediately before analysis, sample $\mathrm{pH}$ was adjusted to 3 by addition of $50 \%$ phosphoric acid. Samples were injected into a Shimadzu TOC-500 high-temperature combustion carbon analyzer in duplicate. Coefficient of variation for DOC analysis averaged $3.3 \%$ in April 1997 and $2.0 \%$ in May 1999.

Preparation of estuarine bacterial inoculum. The samples for the bacterial inoculum were sequentially filtered through $5 \mu \mathrm{m}$ (Osmonics, Inc.) and $1.0 \mu \mathrm{m}$ (Corning-Costar) cartridge filters to remove larger particles. A portion of each bacterial inoculum (15 l) was filtered onto a $293 \mathrm{~mm}$ diameter Poretics $0.2 \mu \mathrm{m}$ filter (Osmonics, Inc., Livermore, CA) and frozen at $-70^{\circ} \mathrm{C}$ for later DNA extraction. The remainder was stored at 
$4^{\circ} \mathrm{C}$ until used to inoculate the enrichment experiments.

Enrichment experiments. A multi-stage enrichment protocol was followed in which estuarine bacterial communities were inoculated into flasks containing DOC fractions and allowed to develop for 3 successive periods (approximately 2 wk each). Each enrichment consisted of the following: HMW or LMW fraction of DOC (final concentration of $10 \mathrm{mg} \mathrm{Cl}^{-1}$ [April 1997] or $6.3 \mathrm{mg} \mathrm{Cl}^{-1}$ [May 1999]); an inorganic nutrient mixture (final concentration of $5 \mathrm{mM} \mathrm{NH}_{4} \mathrm{Cl}, 5 \mathrm{mM} \mathrm{NaNO}_{3}$, and $\left.1 \mathrm{mM} \mathrm{NaH}_{2} \mathrm{PO}_{4}\right) ; 5 \mathrm{ml}$ of the size-fractionated bacterial inoculum (final cell density of $10^{4} \mathrm{ml}^{-1}$ ); and, concentrated artificial seawater to bring the salinity to $30 \mathrm{psu}$ (the amount of which varied depending on whether the salts partitioned with the fraction during ultrafiltration [LMW fraction] or not [HMW fraction]). The first and second enrichment stages consisted of duplicate flasks containing $500 \mathrm{ml}$ of medium (i.e., DOC fraction plus nutrients and sea salts), and the third stage consisted of duplicate flasks containing 31 of medium. Each stage was inoculated with a volume from the previous stage equivalent to $5 \%$ of the new volume. An additional treatment consisting of unfractionated (whole) DOC was included in the May 1999 experiment at the same DOC concentration as the individual LMW and HMW treatments $\left(6.3 \mathrm{mg} \mathrm{Cl}^{-1}\right)$. For this treatment, 2 replicate enrichments were established and transferred as described above, but contained unfractionated Satilla River water (i.e., both the LMW and HMW fractions were present). At the conclusion of each stage, bacterial cells were filtered onto $0.2 \mu \mathrm{m}$ polycarbonate filters for subsequent DNA extraction.

Biological utilization assay. Concomitantly with the beginning of the third stage of the enrichment, a biological utilization assay was conducted by filling six $60 \mathrm{ml}$ BOD bottles with inoculated enrichment medium. Three bottles were immediately fixed with Winkler reagents to determine initial dissolved oxygen concentrations. All bottles were incubated underwater in the dark at $20^{\circ} \mathrm{C}$ for $2 \mathrm{wk}$ (i.e., the same period of time as the third enrichment stage). At the end of the incubation, the other 3 bottles were fixed with Winkler reagents and initial and final oxygen concentrations were measured using the Mettler Toledo DL21 automated titrator (Mettler Toledo, Columbus, $\mathrm{OH}$ ) (Pomeroy et al. 1994).

DNA extraction. DNA was obtained from the inoculum and after the third stage of the enrichment for the April 1997 and May 1999 studies. In the April study, additional DNA samples were obtained after the first and second enrichment stages. DNA was extracted according to the method of Tsai \& Olson (1991) as modified by González et al. (1996). Briefly, polycarbonate filters were cut into small pieces and placed in $15 \mathrm{ml}$ sterile tubes containing $15 \mathrm{mg} \mathrm{ml}^{-1}$ of lysozyme in $2 \mathrm{ml}$ of enzyme buffer (0.15 M NaCl, 0.1 M EDTA; $\mathrm{pH} 8.0)$. After incubation at $37^{\circ} \mathrm{C}$ for $2 \mathrm{~h}, 2 \mathrm{ml}$ of lysis buffer (0.1 M NaCl, 0.5 M Tris [pH 8.0], and 10\% SDS) were added, tubes were vortexed, and 3 freeze-thaw cycles (30 min at $-70^{\circ} \mathrm{C}, 5 \mathrm{~min}$ at $65^{\circ} \mathrm{C}$ ) were completed. The supernatant was extracted sequentially with saturated phenol, phenol-chloroform-isoamyl alcohol (25:24:1, $\mathrm{v} / \mathrm{v})$, and chloroform-isoamyl alcohol $(24: 1, \mathrm{v} / \mathrm{v})$. DNA was precipitated overnight in isopropanol at $-70{ }^{\circ} \mathrm{C}$ and washed with ice-cold $70 \%$ ethanol. Dried pellets were resuspended in sterile water and frozen at $-70^{\circ} \mathrm{C}$. The concentration of DNA in extracts was quantified with a DyNAQuant Fluorometer (Amersham Pharmacia Biotech, Piscataway, NJ) using Hoecsht dye 33258 (Sigma).

PCR amplification and clone library construction. 16S rRNA clone libraries were constructed for 3 DNA samples from the April 1997 experiment: the inoculum, the third stage HMW enrichment, and the third stage LMW enrichment. PCR amplification of nearly complete 16S rRNA genes was conducted with the general bacterial primers 8F (AGAGTTTGATCCTGGCTCAG; Liu et al. 1997) and 1525R (AAGGAGGTGATCCAGCC; Embley 1991). The PCR reaction mixture contained the following: $25 \mathrm{ng}$ of DNA, $0.1 \mathrm{mM}$ (each) dNTP, $100 \mathrm{nM}$ (each) primer, $5 \mathrm{mM} \mathrm{MgCl} 2,1 \mathrm{U}$ Thermalase rec- $\mathrm{TBr}$ (Amersco, Solon, OH), and sterile water to bring the reaction to a final volume of $50 \mu \mathrm{l}$. Beginning with a hot start at $82^{\circ} \mathrm{C}$ for 10 min and preheating at $94^{\circ} \mathrm{C}$ for $3 \mathrm{~min}, \mathrm{PCR}$ was conducted for a total of 45 cycles using the following conditions: $94^{\circ} \mathrm{C}$ for $1 \mathrm{~min}, 55^{\circ} \mathrm{C}$ for $1 \mathrm{~min}$, and $72^{\circ} \mathrm{C}$ for $2 \mathrm{~min}$. PCR amplification was confirmed via gel electrophoresis with a $1 \%$ agarose gel stained with ethidium bromide.

PCR products were cleaned with the Wizard Prep DNA Cleanup Kit (Promega, Madison, WI) and cloned with the PT7Blue T-Vector Kit (Novagen, Madison, WI). For each library, 60 to 100 clones were chosen at random and screened for the presence of a complete insert (ca $1500 \mathrm{bp}$ ) by reamplification and visualization of the 16S rRNA gene insert on a $1 \%$ agarose gel. Only clones with complete inserts were used for further analysis.

Clones from each library were grouped into operational taxonomic units (OTUs) using RFLP analysis. PCR products were digested with $5 \mathrm{U}$ of the restriction enzyme HaeIII (Roche Biochemicals, Indianapolis, IN) and visualized on $4 \%$ agarose gels. RFLP patterns and fragment lengths were determined with AlphaEase (version 3.3d) image analysis software on the AlphaImager 2000 Documentation and Analysis System (Alpha Innotech Corporation, San Leandro, CA).

Representative clones of each OTU were sequenced unidirectionally with the $8 \mathrm{~F}$ primer (University of 
Georgia Molecular Genetics Instrumentation Facility, Athens, GA), recovering 400 to $500 \mathrm{bp}$ of sequence information. For each sequence, the closest relative was determined by comparison to the GenBank sequence database.

T-RFLP analysis of enrichment samples. To determine T-RFLP patterns, DNA samples were purified with Sephadex G-75 spin columns (Moran et al. 1995) and used in PCR amplifications. The forward primer was a mixture of labeled (with 6-FAM; Applied Biosystems, Foster City, CA) $(0.18 \mu \mathrm{M})$ and unlabeled primer (0.02 $\mu \mathrm{M})$ (González et al. 2000). The PCR reaction mixture was composed of the following components: 20 ng DNA, $25 \mu$ l of MasterAmp Buffer B (Epicentre Technologies, Madison, WI) with $\mathrm{MgCl}_{2}(5.0 \mathrm{mM})$ and dNTP (400 $\mu \mathrm{M}$ each), $0.2 \mu \mathrm{M}$ forward primer combination, $0.2 \mu \mathrm{M}$ reverse primer (1525R), 2 U Taq DNA polymerase (Roche, Molecular Biochemicals), and sterile water to bring the reaction to a final volume of $50 \mu \mathrm{l}$. PCR was conducted for 30 cycles using the following conditions: $94^{\circ} \mathrm{C}$ for $1 \mathrm{~min}, 55^{\circ} \mathrm{C}$ for $1 \mathrm{~min}$, and $72^{\circ} \mathrm{C}$ for $2 \mathrm{~min}$. At the conclusion of the 30 cycles, a final extension step was performed at $72^{\circ} \mathrm{C}$ for $10 \mathrm{~min}$.

PCR products were cleaned with the Wizard PCR Preps DNA Purification System (Promega), and $30 \mathrm{ng}$ of cleaned PCR product was digested for $3 \mathrm{~h}$ at $37^{\circ} \mathrm{C}$ with 1 of 3 restriction enzymes: HhaI, HaeIII (Roche Molecular Biochemicals), or Sau3AI (Promega). Four $\mu$ l of digest were vacuum dried and resuspended in $12 \mu \mathrm{l}$ of deionized formamide plus $1.0 \mu \mathrm{l}$ of the DNA fragment length size standard GeneScan 2500TAMRA (Applied Biosystems). T-RFLP analysis was conducted on an ABI Prism 310 Genetic Analyzer in GeneScan mode (Applied Biosystems). In some cases, alternative fluorescent labels (i.e., HEX or TET) were used in the PCR amplification step; this allowed simultaneous injection of 2 or more samples into the ABI Prism 310 for direct comparison of fragment lengths.

The relative abundance of each peak in the T-RFLP chromatogram was calculated as a percentage of the total area summed over all peaks. Although each TRFLP chromatogram contained 20 or more peaks, only 5 to 15 dominant peaks were evident in most samples. To concentrate analysis on these more abundant amplicons, only the 10 peaks with the largest area were used for subsequent analysis. Hierarchical cluster analysis was used to group chromatograms according to peak presence and relative abundance using KyPlot version 2.0 beta (freeware available at http://www.zdnet.com). T-RFLP profiles were prepared for presentation in Adobe Illustrator 9.0 (Adobe Systems Incorporated, San Jose, CA).

DNA of sufficient quantity for T-RFLP analysis could not be obtained from some of the enrichment stages (for the April 1997 experiment, 1 replicate each of the
LMW Stage 3, HMW Stage 1, and HMW Stage 3; for the May 1999 experiment, 1 replicate each of the Whole and HMW Stage 3). We suspect contamination from DOC coextracting with the DNA as the source of the problem, particularly in the case of the HMW fractions, but several DNA column clean-up methods and a gel purification method were unsuccessful in allowing amplification.

T-RFLP analysis of clone libraries. The $16 \mathrm{~S}$ rDNA clone libraries were screened for use in assigning identity to the peaks in the enrichment T-RFLP fingerprints. The predicted fragment size for each OTU in the 3 clone libraries was determined using a Visual Basic program that estimates the position of the first cut for any given restriction enzyme (González et al. 2000). These predicted fragment lengths were then confirmed empirically by subjecting a representative of each OTU to T-RFLP analysis. Methods were nearly identical to those used for community DNA (as described above) except for the following modifications: the Sephadex G-75 clean-up step was omitted, $5 \mathrm{ng}$ of DNA were used in amplifications, and only $1 \mu \mathrm{l}$ of digest was used for GeneScan analysis. Finally, OTUs putatively identified as the source of peaks in the community chromatograms by these methods were confirmed by coinjection with the community sample. Clone inserts were amplified with a forward primer labeled with a dye of alternate color (i.e., HEX or TET labeled 8F). The clone and community samples were then digested separately with HhaI and simultaneously injected into the ABI310 for GeneScan analysis.

\section{RESULTS}

\section{Organic matter processing}

Initial DOC concentrations in the April 1997 and

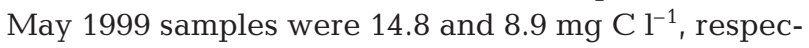
tively (Table 1). Mass balance calculations indicated that $87 \%$ (April 1997) and 88\% (May 1999) of the original DOC was recovered in the sum of the LMW and HMW fractions. There was a substantial difference in the distribution of carbon between size classes for the 2 initial water samples used for the experiments: the HMW fraction comprised $57 \%$ of the DOC in April 1997 and $26 \%$ in May 1999, while the LMW fraction comprised $30 \%$ of the total DOC in April 1997 and $62 \%$ in May 1999.

\section{DOC enrichments}

The biological utilization assays showed distinct differences in the utilization of DOC based on MW size 
Table 1. Percent contribution of MW fractions to the DOC pool and percent utilization during the final enrichment stage

\begin{tabular}{|c|c|c|c|c|}
\hline $\begin{array}{l}\text { DOC } \\
\text { fraction }\end{array}$ & $\begin{array}{c}\% \text { of total } \\
\text { DOC }\end{array}$ & $\begin{array}{l}\text { Enrichment } \\
\text { concentration } \\
\left(\mathrm{mg} \mathrm{C} \mathrm{l}^{-1}\right)\end{array}$ & $\begin{array}{c}\mathrm{C} \text { normalized } \\
\text { respiration } \\
\left(\mu \mathrm{M} \mathrm{O}_{2} \mathrm{mg} \mathrm{C}^{-1}\right)\end{array}$ & $\begin{array}{c}\% \text { DOC } \\
\text { respired }^{\mathrm{a}}\end{array}$ \\
\hline \multicolumn{5}{|c|}{ April 1997} \\
\hline LMW & 30 & 10 & 13.2 & 15.8 \\
\hline HMW & 57 & 10 & 1.1 & 1.3 \\
\hline \multicolumn{5}{|c|}{ May 1999} \\
\hline LMW & 62 & 6.3 & 6.2 & 7.4 \\
\hline HMW & 26 & 6.3 & 1.7 & 2.0 \\
\hline Whole & 100 & 6.3 & 1.8 & 2.2 \\
\hline
\end{tabular}

(Fig. 1A,B). In both experiments, bacterial respiration was higher in the LMW enrichments than in either the HMW or Whole DOC enrichments. Carbon-normalized respiration rates were an order of magnitude higher on LMW than on HMW DOC in the April 1997 experiment (Fig. 1A), although the difference was less than 4-fold in the May 1999 experiment (Fig. 1B). Respiration in the May 1999 Whole treatment was more than 2-fold lower than the rate predicted based on respiration in the LMW and HMW fractions and their percent contribution to the DOC pool (1.8 [measured] vs 4.3 [predicted] $\mathrm{MM} \mathrm{O}_{2} \mathrm{mg} \mathrm{C}^{-1}$ ). This discrepancy suggests that the ultrafiltration procedure may have increased the biological availability of the DOC, particularly that of the LMW fraction. Physical disruption of liposomes (Borch \& Kirchman 1999) or other macromolecular organic structures (Nagata et al. 1998) is one possible explanation for this result.

\section{Screening of April 1997 16S rDNA clone libraries}

A total of 150 clones were analyzed from the 3 clone libraries (41 clones from the inoculum library, 53 from the LMW library, and 56 from the HMW library). Based on RFLP screening, the clones were placed in 31 OTUs (Table 2). Sequence analysis of several representatives from each OTU indicated that 56 clones were affiliated with the $\alpha$-Proteobacteria (37\% of total), 24 were $\beta$ Proteobacteria (16\%), 51 were $\gamma$-Proteobacteria (34\%), 1 was $\delta$-Proteobacteria $(0.7 \%), 14$ were $\varepsilon$-Proteobacteria $(9 \%), 3$ were Cytophaga-Flexibacter-Bacteroides (CFB) (2\%), and 1 was Planctomycetes (0.7\%) (Table 2).

The clone libraries indicated that the composition of the HMW and LMW enrichment communities differed from one another and from the inoculum community (Table 2). The inoculum and HMW clone libraries were dominated by $\alpha-, \beta$-, and $\gamma$-Proteobacteria (accounting for 54,27 , and $15 \%$ in the inoculum library and 52, 23, and $20 \%$ in the HMW library). In contrast, the LMW library was dominated by $\gamma$ - and $\varepsilon$-Proteobacteria clones (accounting for 64 and $26 \%$ of the clones).

The dominant $\alpha$-Proteobacteria in the inoculum community were members of the Roseobacter lineage, including OTUs EC-I1 and EC-I50, and the SAR11 cluster (Table 2), a group routinely recovered in marine clone libraries (Field et al. 1997, Rappé et al. 1997). The major $\alpha$-Proteobacterial group in the HMW library (EC-B2) was most closely related to the Rhizobium-Agrobacterium group. The most abundant group of $\beta$-Proteobacteria in the inoculum (EC-I19) was related to a group of methylotrophic bacteria typically recovered from coastal and freshwater ecosystems (Rappé et al. 2000). In the HMW library, all of the $\beta$ Proteobacteria clones (represented by OTU EC-B4) were nearly identical (99.5\%) to Janthinobacterium lividum. $\gamma$-Proteobacteria clones in all 3 libraries were related to Pseudomonas and Oceanospirillum isolates and clones typically retrieved from marine envi-
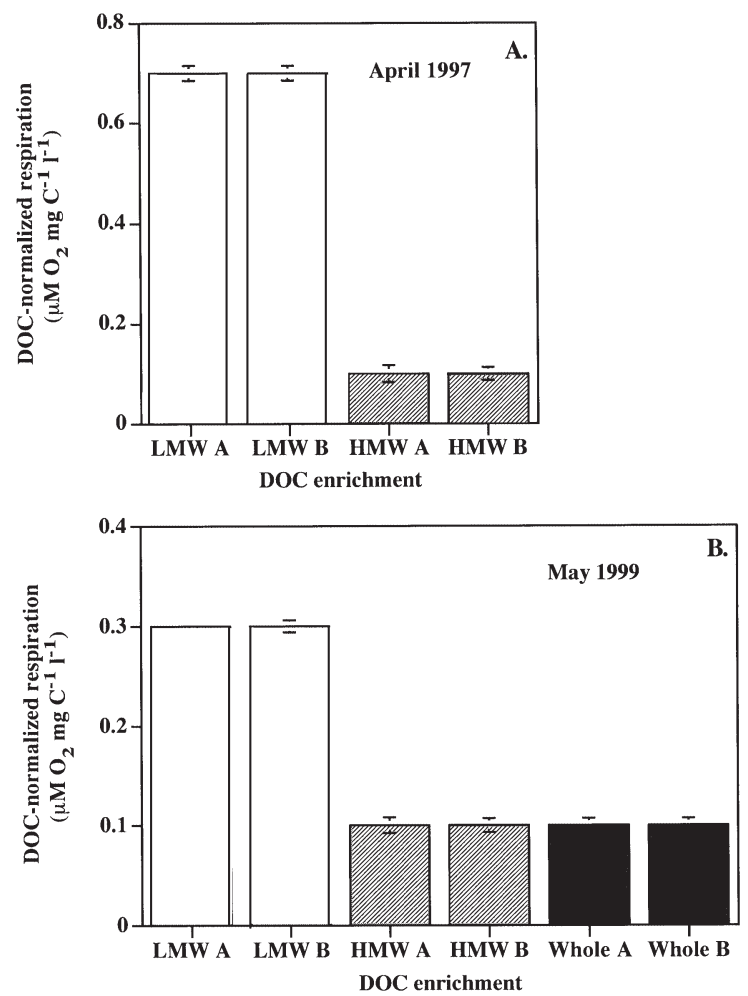

Fig. 1. DOC-normalized bacterial respiration of DOC MW size classes in stage 3 enrichments from (A) April 1997 and (B) May 1999 experiments. Error bars indicate 95\% confidence intervals 


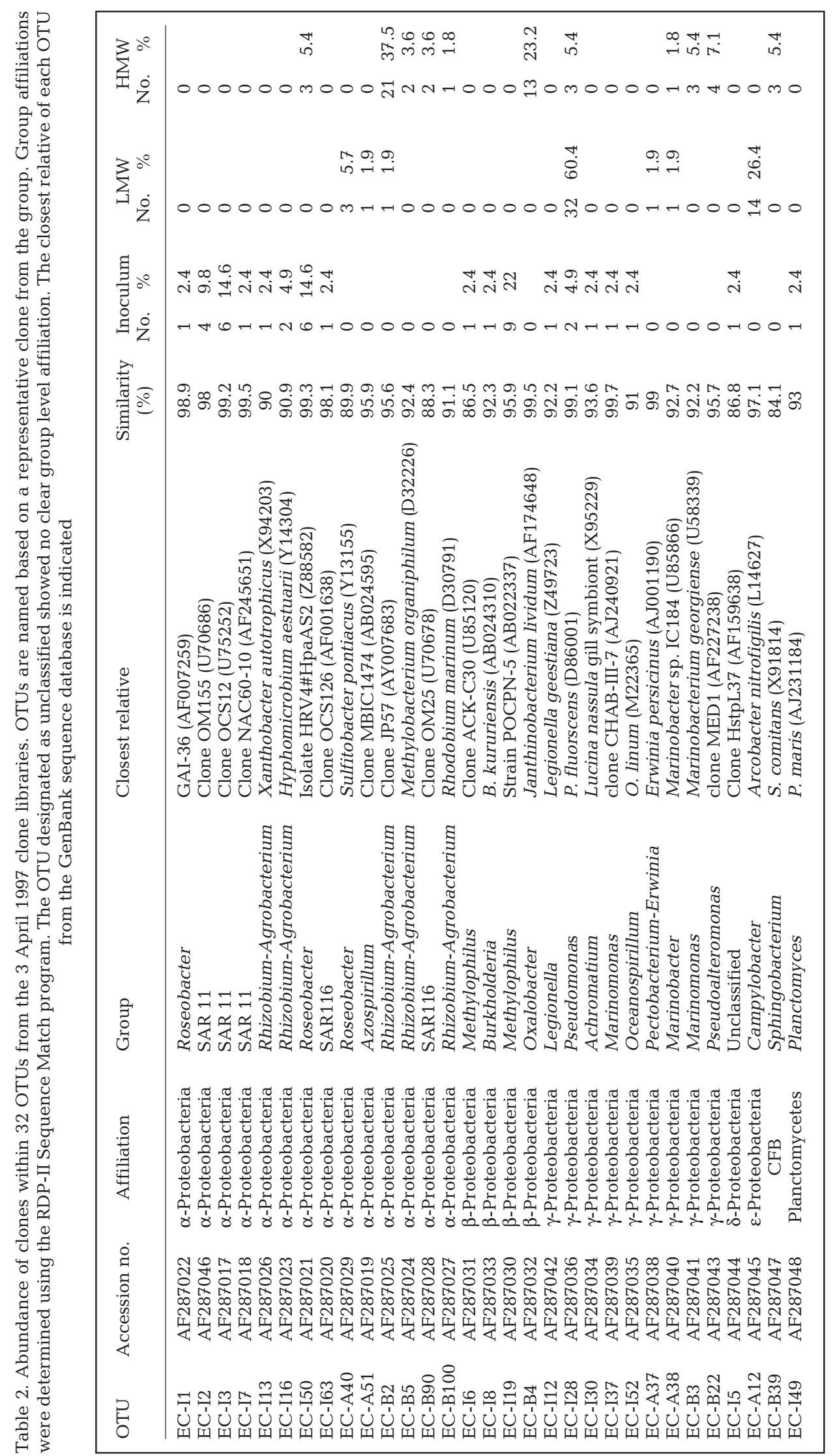

ronments. These included Pseudomonas fluorescens (EC-I28) in the inoculum, HMW, and LMW libraries; Oceanospirillum linum (ECI52) in the inoculum library; and Marinobacterium georgiense (EC-B3) and Pseudoalteromonas-related clone MED1 (EC-B22) in the HMW library. $\delta$-Proteobacteria were recovered only from the inoculum library with 1 OTU (EC-I5) representing this lineage. Likewise, $\varepsilon$-Proteobacteria (ECA12, related to Arcobacter nitrofigilis) were only recovered from the LMW library.

Additional groups included OTUs related to isolates or clones in the CFB phylum and the Planctomycetes group. Clones within the CFB group were recovered only from the HMW clone library (EC-B39; $5.4 \%$ ), while Planctomycetes were recovered only from the inoculum (EC-I49; 2.4\%).

Coverage values for each library were calculated according to the equation $C=$ $[1-(n / N)] \times 100$, where $C=$ coverage, $n=$ number of unique clones (clones which occurred only once in a library), and $N=$ total number of clones (Good 1953, Mullins et al. 1995). Coverage values indicate that $71 \%$ of the amplicon diversity associated with the inoculum library was sampled, while 92 and $96 \%$ of the amplicon diversity in the LMW and HMW libraries was sampled (Table 2).

\section{T-RFLP characterization of enrichment communities}

T-RFLP profiles were obtained for 10 samples from the April 1997 experiment and 5 from the May 1999 


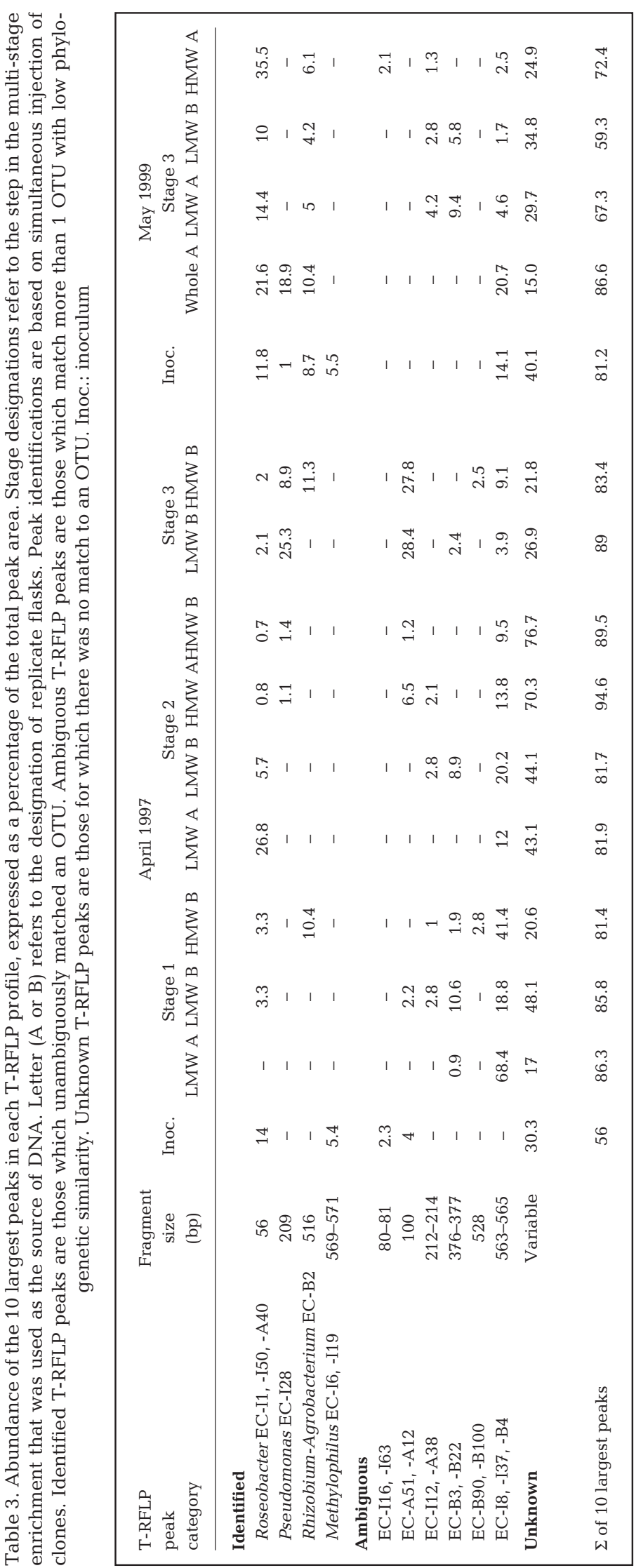

experiment. All samples were co-injected and analyzed with at least 1 other sample (maximum of 3 samples per injection) to insure consistent size calling of peaks. Analysis of replicate PCR reactions from the same DNA sample produced highly reproducible profiles (data not shown). Fragment sizes $>600$ bp were excluded from analysis.

The quantitative comparisons among T-RFLP chromatograms was based on the 10 peaks with the highest relative area for each community. These 10 largest peaks accounted for an average of $80 \%$ of the total peak area in the chromatograms, and in one case for as much as $95 \%$ (Table 3), indicating that a large fraction of the 16S rRNA amplicons were included in the community characterization. Cluster analysis showed that the samples grouped into 4 major branches that roughly coincided with treatment (i.e., inoculum, HMW, or LMW; Fig. 2). Grouping with the HMW samples were a LMW sample from Stage 3 of the April 1997 experiment and a Whole sample from the May 1999 experiment. Clustering with the 2 inoculum samples was a HMW sample from the May 1999 experiment. Cluster analysis was also performed using only presence/absence data for each peak. This analysis did not show as much clustering based on enrichment types, although some of the clusters were maintained (i.e., HMW97-2-A \& $\mathrm{B}_{i}$ LMW-97-1-B, LMW-97-2-B, and LMW-99-3-A; data not shown).

The duplicate enrichment flasks generally showed good reproducibility in the composition of the bacterial community with regard to fragment size and peak area. Similarity in community composition was highest for the Stage $2 \mathrm{HMW}$ replicates from the April 1997 experiment (Fig. 2), for which common peaks accounted for 94.6 and $88.3 \%$ of the total peak area in the 2 replicates (Table 3). Cluster analysis showed that in the remaining cases for which replicate enrichments were analyzed by the T-RFLP method (3 pairs of LMW replicates; Table 3) replicate pairs clustered with one another, but were not always the most similar (Fig. 2).

Within a treatment, the composition of the bacterial community changed during the course of the 3-stage enrichment (Fig. 3). For example, the peaks held in common between the first and third stages of the LWM enrichments in the April 1997 experiment accounted for only $11 \%$ of the chromatogram area. Similarly, only $10 \%$ of area in the April 1997 HMW chromatograms for stages 1 and 3 represented common peaks (Table 3). 


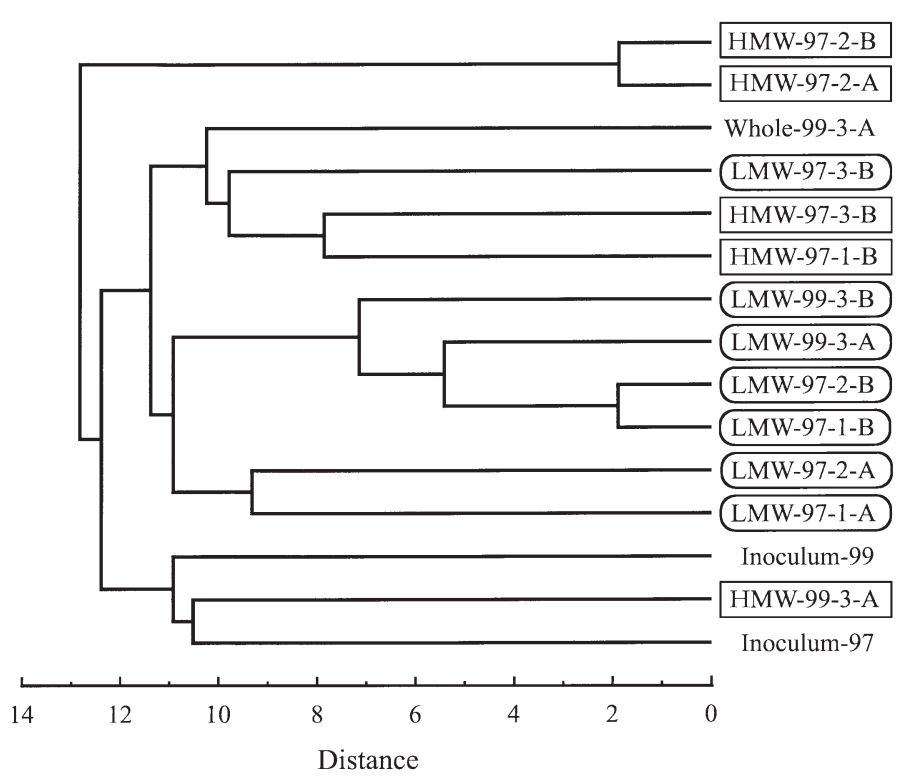

Fig. 2. Dendrogram of the T-RFLP profiles from the DOC enrichments. Similarity calculations are based on the peak area of the 10 most abundant peaks in each sample. Sample notation is based on organic carbon enrichment (HMW, LMW, Whole, or Inoculum), year of experiment (1997 or 1999), stage of experiment (1 to 3 ), and replicate (A or B)

\section{Determination of T-RFLP peak identity}

The length of the terminal restriction fragment for OTUs from the clone libraries was unique in many cases, providing a potential mechanism for assigning taxonomic affiliations to T-RFLP peaks. Problem OTUs were EC-I3 and EC-B39, which did not cut with HhaI, EC-A51 ( $\alpha$-Proteobacteria) and EC-A12 ( $\varepsilon$-Proteobacteria), which both produced $100 \mathrm{bp}$ fragments, and EC-I8 and EC-B4 ( $\beta$-Proteobacteria) and EC-I37 $(\gamma$ -

Fragment size (bp)
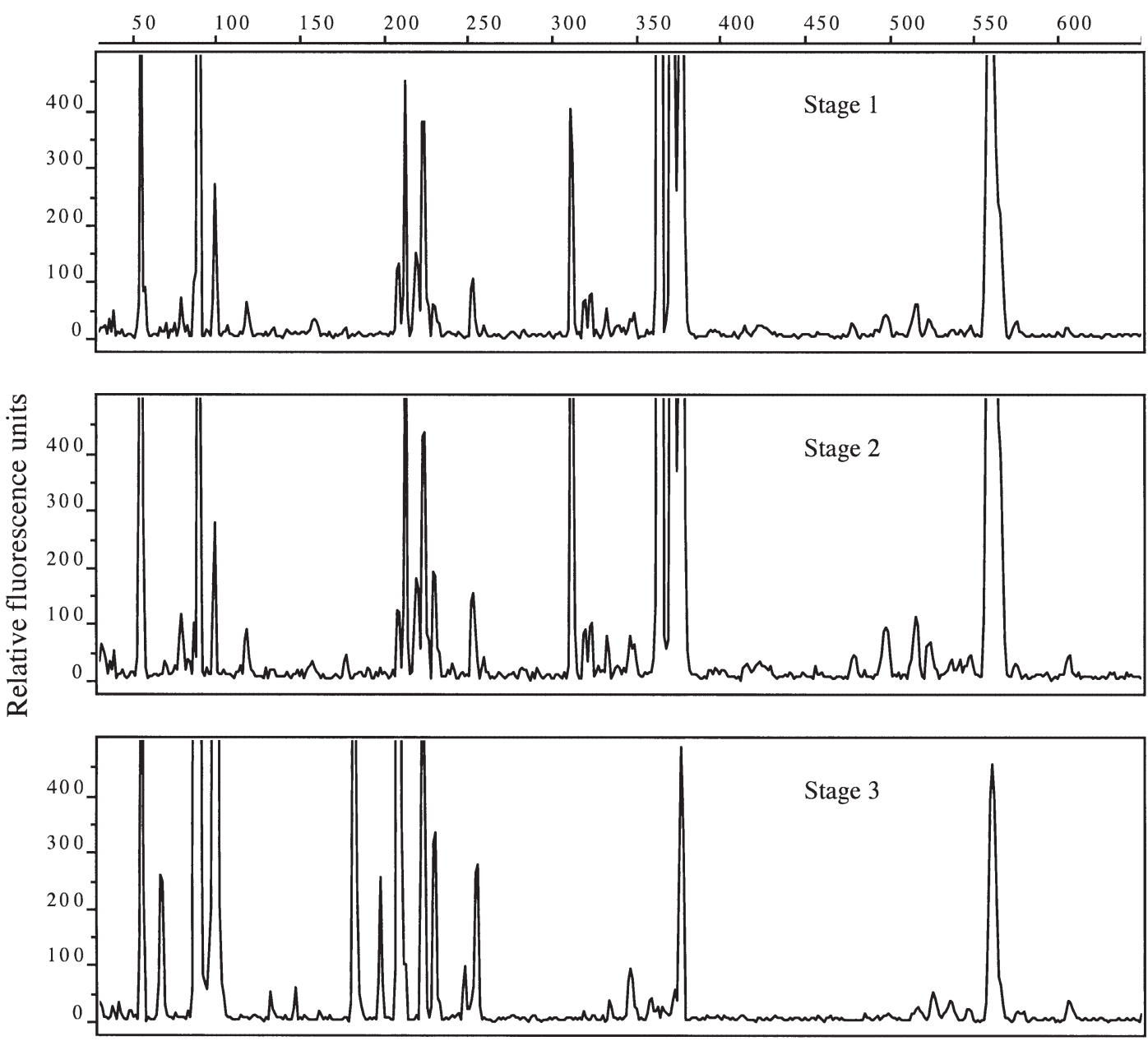

Fig. 3. T-RFLP profiles for 3 successive stages of the LMW enrichment from the April 1997 experiment 
Proteobacteria), which all produced 563 to 565 bp fragments (Table 3). The use of 2 alternative restriction enzymes (HaeIII and Sau3AI) in the digestion step did not successfully resolve these problems without introducing new ones (data not shown).

Using the empirically determined HhaI terminal restriction fragments for each OTU that were confirmed by coinjection of clones and community samples, it was possible to tentatively identify the taxa responsible for only 11 of the 45 major peaks in the enrichment community T-RFLP chromatograms (Table 3, Fig. 4). For the 3 samples that served as the source of the clone libraries (the inoculum and Stage 3 HMW and LMW enrichments from the April 1997 experiment), identified peaks accounted for 19 to $25 \%$ of the total chromatogram area and represented $16 \mathrm{~S}$ rRNA genes from the Roseobacter, RhizobiumAgrobacterium, Pseudomonas, Arcobacter, and
Methylophilus lineages (Tables 2 \& 3). For the samples from earlier stages in the April 1997 enrichments and from the May 1999 enrichments (i.e., those not used for clone library construction), identified peaks accounted for 0 to $51 \%$ of the total peak area (Table 3 ).

\section{DISCUSSION}

Much of the available information on rates and patterns of DOC utilization in aquatic ecosystems has not yet been placed in the context of the bacterial groups that serve as the primary mediators of DOC processing. The goal of this study was to identify specific groups of bacteria that might be implicated in the turnover of HMW and LMW fractions of DOC in a southeastern US estuary. The enrichment culture approach chosen here has the potential disadvantage
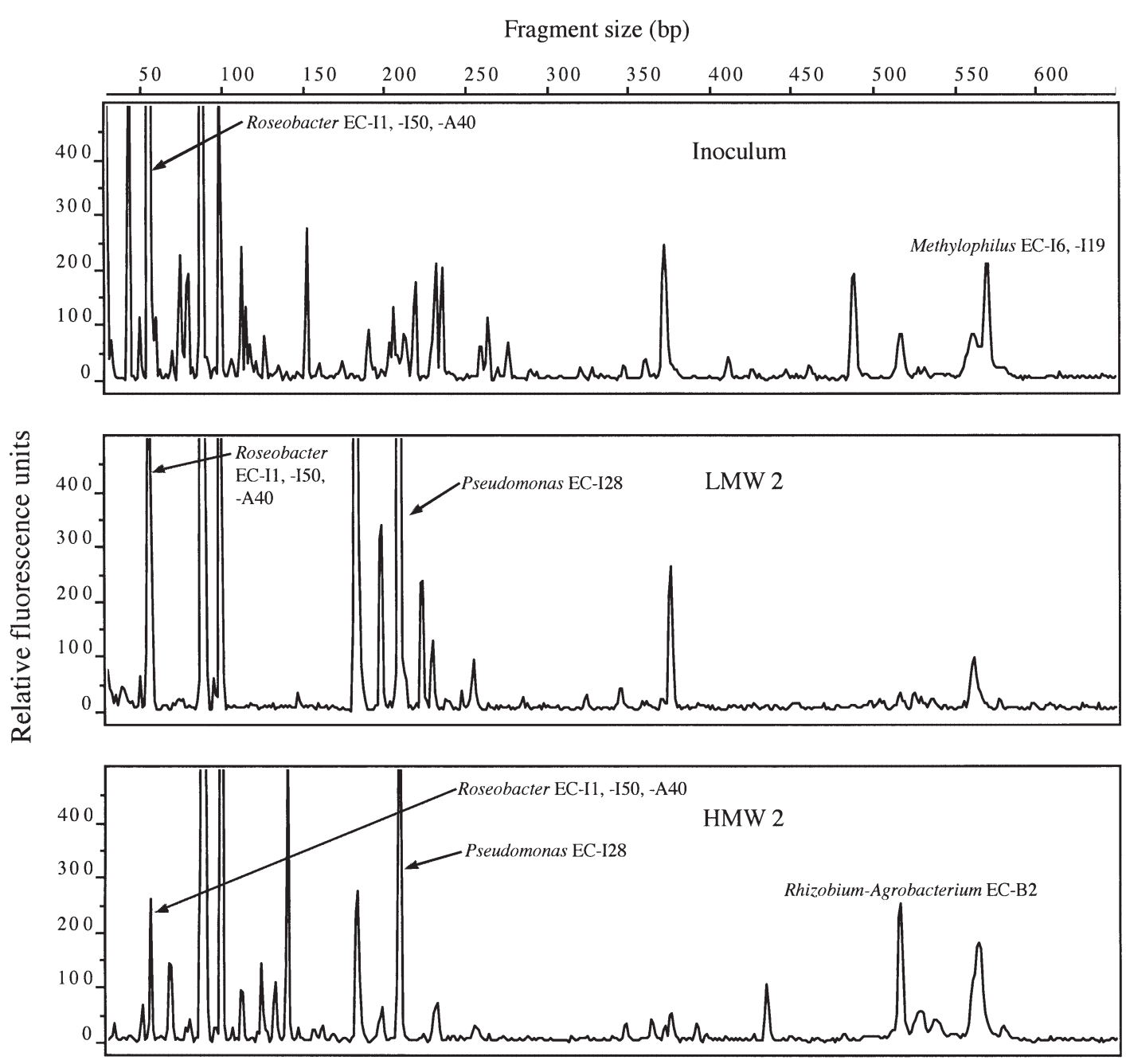

Fig. 4. T-RFLP profiles for the 3 samples for which the clone libraries were constructed (inoculum and Stage 3 enrichments from April 1997). Tentative peak identifications are indicated 
of inducing incubation-related composition shifts in the bacterial community (e.g., Lee \& Fuhrman 1990, Pomeroy et al. 1994) that are unrelated to the enrichment substrate. Nonetheless, it establishes clear sizebased differences in DOC composition over several bacterial generations that can allow for the development of specialized communities.

\section{DOC utilization and implications for community dynamics}

Bacterial utilization of the LMW fraction of DOC was higher (by 10-fold in April 1997 and 4-fold in May 1999) than utilization of the HMW fraction or the whole DOC. Assuming a respiratory quotient of 1.0, we estimate that 15.8 and $1.3 \%$ of the LMW and HMW fractions were consumed during the final stage of the enrichment in April 1997, and 7.4, 2.0, and 2.2\% of the LMW, HWM and whole DOC were consumed in May 1999. Although lower that what has typically been found for freshwater or marine DOC in shorter incubation studies (14 to 19\%; Søndergaard \& Middelboe 1995), these values are similar to those reported in earlier studies of the Satilla River (Hopkinson et al. 1998, Moran et al. 1999).

The greater biological lability of the LMW DOC pool relative to the HMW pool is consistent with some previous studies of size-based bioavailability (Meyer et al. 1987), although not all (Amon \& Benner 1994, 1996). Satilla River DOC has been shown previously to contain high concentrations of soil and vascular plantderived humic substances (Beck et al. 1974), and the HMW fraction of Satilla DOC had the highest aromaticity $(36 \%)$ and highest dissolved lignin content in a survey of eastern US estuaries (Hopkinson et al. 1998). Thus, HMW DOC in this system is likely dominated by refractory vascular plant-derived material, rather than polysaccharides or other labile biopolymers (Moran et al. 2000).

Based on both increases in cell number and carbon utilization calculated from respiration rates (assuming a $20 \%$ carbon conversion efficiency and $20 \mathrm{fg} \mathrm{C} \mathrm{cell}^{-1}$ ), we calculate that the MW fractions supported at least 4 bacterial generations during each stage of the 3 -stage enrichment. These calculations are consistent with the shifts in bacterial community composition observed during the enrichment process (Table 3, Fig. 3).

\section{Phylogenetic composition of enrichment communities}

The phylogenetic range of OTUs found in the three 16S rDNA libraries was comparable to that typically recovered from marine environments (Field et al 1997, Rappé et al. 1997, Cottrell \& Kirchman 2000b) Clones were recovered from all 5 subclasses of Proteobacteria as well as from CFB and Planctomycetes. Although Gram-positive bacteria are commonly found in marine clone libraries (Rappé et al. 1997, Crump et al. 1999), they were the only major bacterial lineage not represented in our libraries. For the majority of phylotypes, the closest relatives were isolates or clones recovered previously from marine systems (Table 2). In 2 cases, phylotypes were most similar to organisms previously cultured from the Georgia coast: OTU EC-I1 was most similar to GAI-36 (98.9\%) (González \& Moran 1997) and OTU EC-B3 was most similar to Marinobacterium georgiense $(92.2 \%)$ (González et al. 1997).

Among the 3 clone libraries, the inoculum library was the most diverse, containing at least one OTU from all taxonomic groups except the $\varepsilon$-Proteobacteria and CFB (Table 2). The inoculum library also had the highest percentage of phylotypes unique across all 3 clone libraries $(79 \%)$ compared to the LMW $(36 \%)$ and HMW (56\%) libraries. The lower diversity of 16S rDNA amplicons in the LMW and HMW enrichment communities may reflect selection for bacteria that grow well in batch incubations. However, there was no overlap in the identity of dominant OTUs between the HMW and LMW libraries, and likewise no clear shifts in composition at the higher taxon level that would indicate the development of 'weed' communities totally independent of available substrate.

The dominant phylotypes in the LMW library were related to Pseudomonas fluorescens and Arcobacter nitrofigilis from the $\gamma$ - and $\varepsilon$-Proteobacterial lineages, respectively. Cultured pseudomonads have typically been characterized as metabolically versatile and capable of degrading a wide range of LMW compounds (Kersters et al. 1996). Arcobacter nitrofigilislike sequences, which were unique to the LMW library, have only recently been identified in environmental settings (Llobet-Brossa et al. 1998, Maugeri et al. 2000). Several phylotypes clustering with the Roseobacter lineage of the $\alpha$-Proteobacteria were also recovered from the LMW library, although their numbers were small relative to the $\gamma$ - and $\varepsilon$ Proteobacteria. The LMW enrichment clone library had no phylotypes in the $\beta$-Proteobacteria or CFB lineages.

In contrast, the HMW library was dominated by phylotypes from the $\alpha-, \beta-$, and $\gamma$-Proteobacteria and the CFB, with $>50 \%$ being $\alpha$-Proteobacteria. The bulk of the $\alpha$-Proteobacteria clones were affiliated with the Rhodobium marinum in the Rhizobium-Agrobacterium group, although these clones exhibited low similarity $(91 \%)$ to their closest relatives. The $\beta$-Proteobacteria 
phylotypes from the HMW library were related to Janthinobacterium lividum (>99\%), a bacterium known to be capable of chitin degradation (Greenwood et al. 1993). The majority of $\gamma$-Proteobacteria phylotypes in the HMW library were related to the Pseudoalteromonas and Marinomonas groups. Some members of the Marinomonas group have been shown to be involved in the degradation of lignin, a high molecular weight phenolic compound (González et al. 1996, 1997). The absence of the methylotrophic $\beta$-Proteobacteria in both the LMW and HMW enrichments despite their importance in the inoculum community suggests either that these groups were not principal mediators of DOC utilization or that they were at an ecological disadvantage in the enrichment cultures. The lone Planctomycetes and $\delta$-Proteobacteria phylotypes were also found only in the inoculum library.

Our 16S rDNA libraries show some similarities with a recent study of bacterial specialization on DOC components that focused at a higher (i.e., division and subdivision) taxonomic level (Cottrell \& Kirchman 2000a). CFB were found only in the HMW library in our study and were also important in the utilization of HMW compounds (protein and chitin) in the Cottrell \& Kirchman (2000a) study. Likewise, $\alpha$-Proteobacteria were involved in the processing of HMW and LMW compounds in both studies. Differences between the 2 studies include the role of $\beta$-Proteobacteria (important in utilization of LMW amino acids in the Cottrell \& Kirchman [2000a] study but not present in our LMW library) and $\gamma$-Proteobacteria (relatively inactive in the Cottrell \& Kirchman [2000a] study but well represented in both the LMW and HMW libraries here).

\section{T-RFLP characterization of enrichment communities}

T-RFLP analysis of the enrichment DNA samples provided a mechanism to make multiple comparisons within and between experiments that would not have been feasible using time-intensive 16S rDNA sequence analysis. The bacterial communities in replicate flasks within an experiment were generally similar in composition, with the percent of peak area held in common varying from a high of $94.6 \%$ (April 1997, HMW Stage 2) to a low of $29 \%$ (May 1999, LMW Stage 3). Cluster analysis based on the 10 most abundant peaks showed 6 out of 7 LMW stages grouping on the same branch of the dendrogram, with the 1 exception being the LMW sample used for 16S rDNA clone library construction (April 1997, LMW Stage 3). Four of the 5 HMW samples clustered on 2 branches, and the 2 inoculum samples (collected 2 yr apart) were also compositionally similar.

\section{Congruity of the 16S rRNA clone libraries and T-RFLP analyses}

The availability of a companion 16S rRNA clone library for 3 of the samples (inoculum, HMW Stage 3, and LMW Stage 3 from the April 1997 experiment) increased the power of the T-RFLP approach by allowing the assignment of specific terminal restriction fragments to a taxon. For example, $56 \mathrm{bp}$ fragments were common in many of the T-RFLP profiles and matched the expected fragment size of Roseobacter phylotypes found in all 3 clone libraries. Although many other $\alpha$ Proteobacteria 16S rRNA genes produce terminal restriction fragments of $56 \mathrm{bp}$ following digestion with HhaI, the Roseobacter phylotypes were the only match from our clone libraries (Table 2). However, because these fragments were found in all 3 clone libraries and in 14 of 15 T-RFLP profiles, the Roseobacter terminal restriction fragments were not diagnostic for taxa specializing on specific DOC fractions.

Another group tentatively identified in the T-RFLP profiles was the Pseudomonas fluorescens related OTU. Phylotypes associated with this group were recovered from all 3 clone libraries and the characteristic peak for this group was found in 6 of the $15 \mathrm{~T}$ RFLP profiles, including the 3 samples used for the clone library construction (Table 3). Similarly, OTU EC-B2 (Rhizobium-Agrobacterium) was found primarily in the HMW clone library ( $37.5 \%$ of clones) and the characteristic peak for this OTU was present in the HMW T-RFLP profile from this sample. Finally, the OTUs related to methylotrophic $\beta$-Proteobacteria ( $24 \%$ of clones) were recovered only from the inoculum, while the corresponding characteristic fragments were present only in the inoculum T-RFLP profiles. The percent of the T-RFLP chromatogram area identified based on the clone libraries ranged from a high of $51 \%$ (May 1999, Whole Stage 3) to a low of 1.9\% (April 1997, HMW Stage 2).

For the 3 samples used to construct the clone libraries, peaks corresponding to major OTUs were generally identified in the T-RFLP profile of that sample (i.e., Roseobacter and Methylophilus in the inoculum; Roseobacter, Pseudomonas, and RhizobiumAgrobacterium in the HMW enrichment; Roseobacter and Pseudomonas in the LMW enrichment). In several cases, however, similarity in restriction fragment size among OTUs of divergent phylogenetic affiliation prevented the unambiguous identification of peaks. Six OTUs with ambiguous terminal restriction fragments were found (Table 3), including the Janthinobacterium lividum-related OTU that was dominant in the HMW library (Table 2). Further, members of the SAR11 group (present only in the inoculum clone library) had a terminal restriction fragment size beyond the point 
where size calling of peaks was reliable. Overall, ambiguous terminal restriction fragments accounted for $6.3 \%$ (April 1997, inoculum) to 69.3\% (April 1997, LMW Stage 1) of the total peak area (Table 3). Finally, peaks for which no affiliation could be determined accounted for 76.7\% (April 1997, HMW Stage 2) to $15.0 \%$ (May 1999, Whole Stage 3) of the peak area (Table 3).

The value of T-RFLP analysis for visualizing large scale patterns in bacterial diversity has been shown previously (Moeseneder et al. 1999, 2001, Dunbar et al. 2000) and at least in some cases has been more successful in identifying terminal restriction fragments based on companion clone libraries (González et al. 2000). Considering the overlap between the HMW and LMW communities at the higher taxon level, particularly for the Pseudomonas and Roseobacter lineages, a more complete accounting of the bacterial groups involved in DOC turnover will require focusing on relationships below the division or subdivision level, using either group-directed T-RFLP analysis (Dunbar et al. 2001) or probes targeting specific 16S rDNA phylotypes.

Acknowledgements. We thank Preethi Lala and Jennifer Ewert for assistance with lab experiments, Dr José González for helpful discussions, and Dr Craig Cary for preliminary discussion about the T-RFLP method. Dr Brian Binder, Dr J. T. Hollibaugh, and 3 anonymous reviewers made helpful comments on the manuscript. This research was supported by the NSF Georgia Rivers LMER Project (DEB-9412089) and the NSF Microbial Observatories Program (MCB-0084164). J.S.C. received additional support from a University of Georgia Graduate School Fellowship.

\section{LITERATURE CITED}

Amon RMW, Benner R (1994) Rapid cycling of high-molecular-weight dissolved organic matter in the ocean. Nature 369:549-552

Amon RMW, Benner R (1996) Bacterial utilization of different size classes of dissolved organic matter. Limnol Oceanogr 41:41-51

Beck KC, Reuter JH, Perdue EM (1974) Organic and inorganic geochemistry of some coastal plain rivers of the southeastern United States. Geochim Cosmochim Acta 38: 341-364

Borch NH, Kirchman DL (1999) Protection of protein from bacterial degradation by submicron particles. Aquat Microb Ecol 16:265-272

Buesseler KO, Bauer JE, Chen RF, Eglinton TI, Gustafsson O, Landing W, Mopper K, Moran SB, Santschi PH, Clark RV, Wells ML (1996) An intercomparison of cross-flow filtration techniques used for sampling marine colloids: overview and organic carbon results. Mar Chem 55:1-31

Coffin RB (1989) Bacterial uptake of dissolved free and combined amino acids in estuarine waters. Limnol Oceanogr 34:531-542

Cottrell MT, Kirchman DL (2000a) Natural assemblages of marine proteobacteria and members of the Cytophaga-
Flavobacter cluster consuming low- and high- molecular weight dissolved organic matter. Appl Environ Microbiol 66:1692-1697

Cottrell MT, Kirchman DL (2000b) Community composition of marine bacterioplankton determined by $16 \mathrm{~S}$ rRNA gene clone libraries and fluorescence in situ hybridization. Appl Environ Microbiol 66:5116-5122

Crump BC, Armbrust EV, Baross JA (1999) Phylogenetic analysis of particle-attached and free-living bacterial communities in the Columbia River, its estuary, and the adjacent coastal ocean. Appl Environ Microbiol 65:3192-3204

Dunbar JL, Ticknor LO, Kuske CR (2000) Assessment of microbial diversity in four southwestern United States soils by $16 \mathrm{~S}$ rRNA gene terminal restriction fragment analysis. Appl Environ Microbiol 66:2943-2950

Dunbar JL, Ticknor LO, Kuske CR (2001) Phylogenetic specificity and reproducibility and new method of analysis of terminal restriction fragment profiles of 16S rRNA genes from bacterial communities. Appl Environ Microbiol 67: 190-197

Embley TM (1991) The linear PCR reaction: a simple and robust method for sequencing amplified rRNA genes. Lett Appl Microbiol 13:171-174

Field, KG, Wright GT, Rappé M, Urbach E, Kergin K, Giovannoni SJ (1997) Diversity and depth-specific distribution of SAR11 cluster rRNA genes from marine planktonic bacteria. Appl Environ Microbiol 63:63-70

Ford TE, Lock MA (1985) A temporal study of colloidal and dissolved organic carbon in rivers: apparent molecular weight spectra and their relationship to bacterial activity. Oikos 45:71-78

Good IJ (1953) The population frequencies of species and the estimation of population parameters. Biometrika 40: $237-264$

González JM, Moran MA (1997) Numerical dominance of a group of marine bacteria in the $\alpha$-subclass of the class Proteobacteria in coastal seawater. Appl Environ Microbiol 63:4237-4242

González JM, Whitman WB, Hodson RE, Moran MA (1996) Identifying numerically abundant culturable bacteria from complex communities: an example from a lignin enrichment culture. Appl Environ Microbiol 62:4433-4440

González JM, Mayer F, Moran MA, Hodson RE, Whitman WB (1997) Microbulbifer hydrolyticus gen. nov., sp. nov., two marine bacteria from a lignin-rich pulp mill waste enrichment community. Int J Syst Bacteriol 47:369-376

González JM, Simó R, Covert JS, Casamayor EO, Pedrós-Alió C, Moran MA (2000) The bacterial community structure associated with a DMSP-producing Atlantic algal bloom. Appl Environ Microbiol 66:4237-4246

Greenwood DR, Taylor RK, Huang CM, Broadwell AH, Kelly WJ (1993) The chitinase of Janthinobacterium lividum. In: Muzzarelli RAA (ed) Chitin enzymology. European Chitin Society, Ancona, p 337-345

Hopkinson CS, Buffam I, Hobbie J, Vallino J, Perdue M, Eversmeyer B, Prahl F, Covert J, Hodson R, Moran MA, Smith E, Baross J, Crump B, Findlay S, Foreman K (1998) Terrestrial inputs of organic matter to coastal ecosystems: an intercomparison of chemical characteristics and bioavailability. Biogeochemistry 43:211-234

Keil RG, Kirchman DL (1991) Contribution of dissolved amino acids and ammonium to the nitrogen requirements of heterotrophic bacterioplankton. Mar Ecol Prog Ser 73:1-10

Kersters K, Ludwig W, Vancanneyt M, DeVos P, Gillis M, Schleifer KH (1996) Recent changes in the classification of the pseudomonads: an overview. System Appl Microbiol 19:465-477 
Lee S, Fuhrman JA (1990) DNA hybridization to compare species compositions of natural bacterioplankton assemblages. Appl Environ Microbiol 56:739-746

Liu WT, Marsh TL, Cheng H, Forney LJ (1997) Characterization of microbial diversity by determining terminal restriction fragment length polymorphisms of genes encoding 16S rRNA. Appl Environ Microbiol 63:4516-4522

Llobet-Brossa E, Roséllo-Mora R, Amann R (1998) Microbial community composition of Wadden Sea sediments as revealed by fluorescence in situ hybridization. Appl Environ Microbiol 64:2691-2696

Maugeri TL, Gugliandolo C, Carbone M, Caccomo D, Fera MT (2000) Isolation of Arcobacter spp. from a brackish environment. Microbiologica 23:143-149

Meyer JL, Edwards RT, Risley R (1987) Bacterial growth on dissolved organic carbon from a blackwater river. Microb Ecol 13:13-29

Moeseneder MM, Arrieta JM, Muyzer G, Winter C, Herndl GJ (1999) Optimization of terminal-restriction fragment length polymorphism analysis for complex marine bacterioplankton communities and comparison with denaturing gradient gel electrophoresis. Appl Environ Microbiol 65: 3518-3525

Moeseneder MM, Winter C, Herndl GJ (2001) Horizontal and vertical complexity of attached and free-living bacteria of the eastern Mediterranean Sea, determined by 16S rDNA and 16S rRNA fingerprints. Limnol Oceanogr 46:95-107

Moran MA, Rutherford LT, Hodson RE (1995) Evidence for indigenous Streptomyces populations in a marine environment determined with a 16S rRNA probe. Appl Environ Microbiol 61:3695-3700

Moran MA, Sheldon WM, Sheldon JE (1999) Biodegradation of riverine dissolved organic carbon in five estuaries of the Southeastern United States. Estuaries 22:55-64

Editorial responsibility: Jed Fuhrman,

Los Angeles, California, USA
Moran MA, Sheldon WM, Zepp RG (2000) Carbon loss and optical property changes during long-term photochemical and biological degradation of estuarine dissolved organic matter. Limnol Oceanogr 45:1254-1264

Mullins TD, Britschgi TB, Krest RL, Giovannoni SJ (1995) Genetic comparisons reveal the same unknown bacterial lineages in Atlantic and Pacific bacterioplankton communities. Limnol Oceanogr 40:148-158

Nagata T, Fukuda R, Koike I, Kogure K, Kirchman DL (1998) Degradation by bacteria of membrane and soluble protein in seawater. Aquat Microb Ecol 14:29-37

Pomeroy LR, Sheldon JE, Sheldon WM (1994) Changes in bacterial numbers and leucine assimilation during estimations of microbial respiratory rates in seawater by the precision Winkler method. Appl Environ Microbiol 60: 328-332

Ramette RW, Culberson CH, Bates RG (1977) Acid-base properties of tris(hydroxymethyl)aminomethane (TRIS) buffers in seawater from 5 to 40 degrees C. Anal Chem 49: 867-870

Rappé M, Kemp PF, Giovannoni SJ (1997) Phylogenetic diversity of marine coastal picoplankton 16S rRNA genes cloned from the continental shelf off Cape Hatteras, North Carolina. Limnol Oceanogr 42:811-826

Rappé MS, Vergin K, Giovannoni SJ (2000) Phylogenetic comparisons of a coastal bacterioplankton community with its counterparts in open ocean and freshwater systems. FEMS Microbiol Ecol 33:219-232

Søndergaard M, Middelboe M (1995) A cross-system analysis of labile dissolved organic carbon. Mar Ecol Prog Ser 118: 283-294

Tsai YL, Olson RH (1991) Rapid method for direct extraction of DNA from soil and sediment. Appl Environ Microbiol 57:1070-1074

Submitted: March 26, 2001; Accepted: July 11, 2001

Proofs received from author(s): August 13, 2001 